\title{
ANALISIS VARIASI WINDOW WIDTH TERHADAP INFORMASI CITRA ANATOMI MSCT STONOGRAFI
}

\author{
Muhammad Izzudin $^{(1)}$, Hermina Sukmaningtyas ${ }^{(2)}$, Nanang Sulaksono ${ }^{(3)}$ \\ ${ }^{1}$ RS Ortopedi Solo \\ ${ }^{2}$ RSUP DR. Kariadi Semarang \\ ${ }^{3}$ Poltekkes Kemenkes Semarang \\ Corresponding author: Muhammad Izzudin \\ e-mail: izzuzu5@gmail.com
}

\begin{abstract}
Background : Multi Slice Computed Tomography is a diagnostic imaging method that can display cross section anatomy in the axial, sagital, and coronal areas. MSCT Stonography imaging both visualizes the anatomy of the urinary tract and stone pathology supported by the presence of ureter tracking techniques and without using contrast media. On this method, the appropriate window width will produce an optimal anatomical picture. The Study aims to determine the effect of window width on anatomical image information on MSCT Stonography.
\end{abstract}

Methods : Type of research is quantitative experimental approach, conducted in January-February 2020 in Hasan Sadikin Bandung hospital, Bandung. Research with variations in window width 300 HU, 350 HU, $400 \mathrm{HU}, 450 \mathrm{HU}$, and $500 \mathrm{HU}$ on MSCT stonography og 10 patients. Criteria's patients is patients with clinical kidney stones, willing to be a research sample. Result imagery rated two respondents, include parenchymal kidney, pelvic calices kidney, ureters, vesica urinary, and stones kidney. Then do Kappa test continued testing Friedman to know the highest mean rank and the influence og the window width oh the image og MSCT stonography.

Results : Based on the result of the Friedman statistical test overall anatomy obtained significance value (p-value $)=0.000<0.05$ means that there is an influence of window width value, the contrast resolution will increase and the better the firm boundary, but the resulting image will be more radioluscent. Based on Friedman's mean rank test result obtained the highest mean rank of 3,54 in a variation of window width 300. The most optical window displays anatomy information using window width 300 .

Conclussion : There are difference in anatomical image information of MSCT stonography among 5 variation window width on examination MSCT stonography. Window width $300 \mathrm{HU}$ is better at anatomy information on MSCT stonography to show better contrast, crisp sharpness, no blur image.

Keywords : window width, MSCT stonography.

\section{Pendahuluan}

Urolithiasis adalah suatu kondisi di area saluran kemih berupa batu kristal yang mengendap di air kemih. Banyak pasien dengan batu kemih tidak memiliki tanda-tanda sama sekali. Gejala pertama terjadi ketika beberapa batu bergerak ke ureter menghambat aliran air kemih dan ginjal. Gejala yang paling umum adalah kolik renal, yaitu rasa sakit yang kuat disebabkan sumbatan atau tegangya otot polos pada saluran ginjal atau saluran kencing (Mehmed \& Ender, 2015). 
Multislice Computed Tomography (MSCT) stonografi merupakan pemeriksaan saluran kemih tanpa menggunakan media kontras oral maupun intra vena (Shaaban dan Kotb, 2015). MSCT merupakan salah satu modalitas untuk mengevaluasi dan mendiagnosa kelainan saluran kemih terutama pada urolithiasis, sehingga MSCT stonografi digunakan sebagai alternatif pengganti pemeriksaan IVU (intravenous urography), karena tidak dapat memberikan diagnostik kualitatif (Niemann, T., dkk, 2010). Menurut Sulaksono N., dkk, (2016) Penggunaan Reconstruction Tracking pada Multislice Computed Tomography (MSCT) Urografi non-kontras mampu menghasilkan citra saluran kemih yang optimal. Serta mampu mengidentifikasi gambaran saluran kemih dengan kasus urolitiasis berupa batu pada ureter (Sulaksono N.,dkk, 2017).

Kualitas citra meliputi semua faktor yang berhubungan dengan akurasi dengan menampakkan struktur dan jaringan organ ke dalam citra. Komponen yang mempengaruhi kualitas citra yaitu spasial resolusi, kontras resolusi, noise dan artefak. Untuk mendapatkan informasi citra yang optimal harus dapat menampilkan gambar dengan kontras yang baik. Salah satu parameter MSCT yang mempengaruhi kontras dan kecerahan dari gambar yaitu nilai window width dan window level (Bontrager, 2018)

Window width merupakan suatu rentang nilai $C T$ number yang digunakan untuk mengatur skala keabu-abuan pada monitor. Proses mengubah skala abu-abu atau grayscale pada MSCT dengan mengatur window width dan window level disebut dengan windowing. Nilai window width akan berpengaruh terhadap kontras gambar, semakin tinggi window width yang digunakan maka kontras dari gambar akan berkurang atau menurun. Dengan pemilihan window width yang tepat, maka gambar MSCT yang dihasilkan dapat memberikan informasi diagnostik yang optimal (Seeram, 2018).
Menurut literatur kepustakaan yang ada window width yang digunakan pada MSCT stonografi yaitu 300 HU-500 HU (Bontrager, 2018), 400 HU (Merrill, 2016), 350 HU (Seeram, 2018), 300 HU (Chou, 2005), 350 HU (Romain, 2010), 400 HU (Andersson, 2012), 400 HU (Yasir dkk, 2015), sedangkan peneliti menjumpai pengaturan nilai window width di Rumah Sakit Hasan Sadikin Bandung menggunakan nilai window width 400 HU. Tujuan penelitian ini untuk mengetahui pengaruh variasi window width terhadap informasi citra anatomi MSCT stonografi dan nilai variasi yang optimal dalam menampilkan informasi citra anatomi pada MSCT stonografi.

\section{Metode}

Jenis penelitian yaitu penelitian kuantitatif dengan pendekatan eksperimental, dilakukan pada bulan Januari-Februari 2020 di Instalasi Radiologi Rumah Sakit Hasan Sadikin Bandung. Responden yang melakukan penilaian informasi citra anatomi yaitu berjumlah dua orang dokter spesialis radiologi dengan pengalaman keterampilan membaca hasil citra MSCT tiap responden yaitu responden pertama memiliki pengalaman tujuh tahun dan responden kedua memiliki pengalaman enam tahun.

Sampel pada penelitian ini sebanyak sepuluh orang data pasien yang terdiri dari enam orang laki-laki dan empat orang perempuan, rentang usia $<50$ tahun sebanyak tiga orang dan $>50$ tahun sebanyak tujuh orang.

Modalitas MSCT yang digunakan adalah merk Hitachi Scenaria 128 slices. Parameter yang digunakan pada pemeriksaan MSCT stonografi tersebut adalah tegangan tabung : $120 \mathrm{kV}$, arus : 10 $\mathrm{mA}$, Slice thickness $10.00 \mathrm{~mm}$, Scan time : 12,63 s, window level : $40 \mathrm{HU}$. Citra hasil penelitian tersebut disimpan dalam bentuk gambar dengan format JPEG tanpa ada keterangan identitas apapun, hanya diberikan kode serial citra dengan kode 1 sebagai window width : $300 \mathrm{HU}$, kode 2 
sebagai window width : $350 \mathrm{HU}$, kode 3 sebagai window width : $400 \mathrm{HU}$, kode 4 sebagai window width : $450 \mathrm{HU}$, kode 5 sebagai window width : $500 \mathrm{HU}$.

Kemudian responden akan memberikan penilaian informasi citra anatomi pada citra MSCT stonografi. Anatomi yang dinilai dalam penelitian ini adalah parenkim ginjal, pelvic calices ginjal, ureter, vesica urinaria, dan tambahan yaitu batu ginjal, dengan skala penilaian dibagi menjadi tiga yaitu skor penilaian (1) dengan arti tidak jelas, apabila anatomi yang diamati kurang jelas bahkan menyulitkan dalam menemukan informasi anatomi pada citra. Skor (2) dengan arti jelas, apabila anatomi yang diamati terlihat jelas, berbatas tidak tegas, dan responden harus lebih teliti dalam mengamati. Skor (3) dengan arti sangat jelas, apabila anatomi yang diamati terlihat jelas, berbatas tegas dan mudah dilihat responden.

Data kemudian diolah menggunakan SPSS 23.0 dengan uji statistik. Uji statistik pertama adalah Cohen's Kappa untuk mengetahui tingkat persamaan persepsi antar responden. Kemudian dilanjutkan dengan analisis uji statistik Friedman untuk melihat apakah ada perbedaan dan untuk melihat nilai yang baik dari interpretasi nilai mean rank. Nilai mean rank tertinggi akan dijadikan nilai window width yang optimal pada MSCT stonografi.

\section{Hasil dan Pembahasan}

Hasil citra yang diperole $\mathrm{h}$ dari 10 pasien pada pemeriksaan MSCT stonografi dengan variasi window width $300 \mathrm{HU}, 350 \mathrm{HU}, 400 \mathrm{HU}, 450 \mathrm{HU}$, dan 500 HU pada pesawat MSCT Hitachi Scenaria 128 slices berjumlah 50 citra MSCT stonografi dimana masing masing menampakan parenkim ginjal, pelvic calices ginjal, ureter, vesica urinaria, dan tambahan batu ginjal. Adapun hasil citra MSCT stonografi salah satu sampel adalah sebagai berikut :
Gambaran citra MSCT stonografi dengan variasi window width terlihat pada gambar 1 sampai dengan gambar 5 dengan kode yang sudah dibahas sebelumnya.

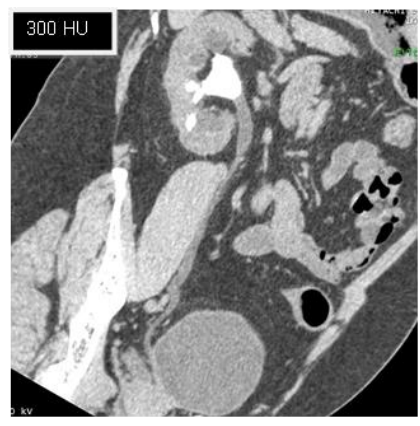

Gambar 1. Citra MSCT stonografi WW 300 HU

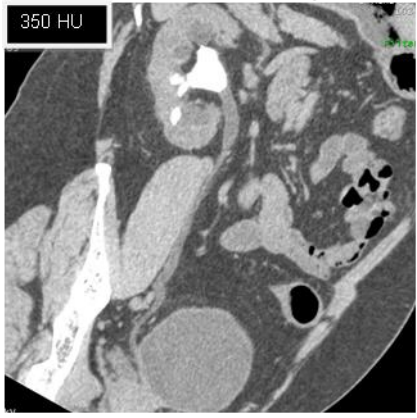

Gambar 2. Citra MSCT stonografi WW 300 HU

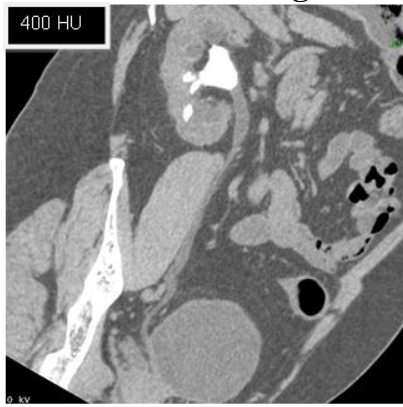

Gambar 3. Citra MSCT stonografi WW 300 HU

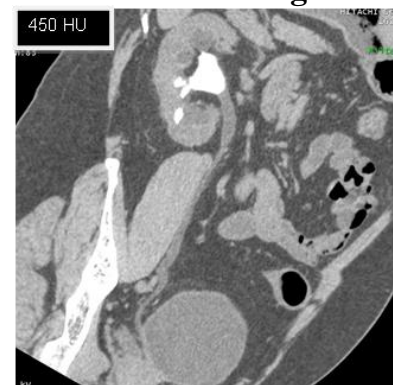

Gambar 4. Citra MSCT stonografi WW 300 HU 


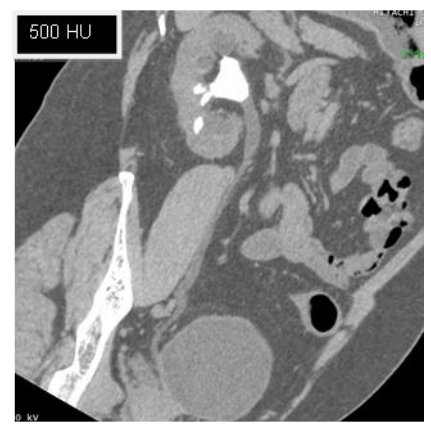

Gambar 5. Citra MSCT stonografi WW 300 HU

Pengujian statistika yang pertama dilakukan adalah uji Cohen's Kappa dengan hasil pengujian Cohen's Kappa terhadap kedua responden adalah sebagai berikut :

Tabel 1. Hasil Uji Cohen's Kappa

\begin{tabular}{|c|c|c|}
\hline Uji Kappa & P Value & Kesimpulan \\
\hline $\begin{array}{c}\text { Responden 1 } \\
\text { dan } \\
\text { Responden 2 }\end{array}$ & 0.681 & Reabilitas Kuat \\
\hline
\end{tabular}

Berdasarkan tabel tersebut, hasil

perhitungan statistika Uji Cohen's Kappa yang diperoleh terdapat pada rentang kesepakatan kuat, sehingga peneliti dapat menggunakan data penilaian kejelasan informasi citra anatomi dari salah satu responden. Dalam hal ini peneliti menggunakan data yang diperoleh dari responden pertama yang memiliki pengalaman paling lama dalam membaca cita MSCT.

Selanjutnya karena data informasi citra yang didapatkan berupa data ordinal sehingga data berdistribusi tidak normal, maka digunakan uji Friedman untuk mengetahui perbedaan sekaligus mengetahui pengaruh variasi window width terhadap informasi citra MSCT stonografi.

Tabel 2. Hasil Uji Friedman Variasi Window Width

\begin{tabular}{|c|c|c|c|}
\hline $\begin{array}{l}\text { Variasi } \\
\text { WW }\end{array}$ & $\begin{array}{c}\text { Asymps. } \\
\text { Sig }\end{array}$ & $\begin{array}{l}\text { Mean } \\
\text { Rank }\end{array}$ & Makna \\
\hline 300 & \multirow{5}{*}{0,000} & 3,54 & \multirow{5}{*}{$\begin{array}{l}\text { Ada } \\
\text { Beda }\end{array}$} \\
\hline 350 & & 3,48 & \\
\hline 400 & & 3,14 & \\
\hline 450 & & 2,74 & \\
\hline 500 & & 2,30 & \\
\hline
\end{tabular}

Berdasarkan tabel 2. Terlihat nilai asymp. Signifikansi dari uji friedman variasi window width pada informasi citra anatomi secara keseluruhan adalah $\mathrm{p}<0,05$ yang menandakan bahwa terdapat perbedaan rata-rata pada masing-masing variasi window width.

Kemudian dilanjutkan dengan uji friedman tiap anatomi pada citra MSCT stonografi. Uji ini dilakukan dengan tujuan untuk mengetahui niali window width mana yang paling baik dalam menampakkan citra masing-masing bagian anatomi, dan hasilnya sebagai berikut :

a. Pada anatomi parenkim ginjal, signifikansi variasi WW pada anatomi tersebut yaitu 0.001 $(\mathrm{p}<0,05)$, artinya ada pengaruh perubahan nilai window width terhadap informasi anatomi parenkim ginjal.

b. Pada anatomi pelvic calices ginjal, signifikansi variasi WW pada anatomi tersebut yaitu 0.009 $(\mathrm{p}<0,05)$, artinya ada pengaruh perubahan nilai window width terhadap informasi anatomi pelvic calices ginjal.

c. Pada anatomi ureuter, signifikansi variasi WW pada anatomi tersebut yaitu $0.009(\mathrm{p}<0,05)$, artinya ada pengaruh perubahan nilai window width terhadap informasi anatomi ureter.

d. Pada anatomi parenkim ginjal, signifikansi variasi WW pada anatomi tersebut yaitu 0.001 $(\mathrm{p}<0,05)$, artinya ada pengaruh perubahan nilai window width terhadap informasi anatomi vesica urinaria.

e. Pada batu ginjal, signifikansi variasi WW tersebut yaitu 0.406 ( $p>0,05)$, artinya tidak ada pengaruh perubahan nilai window width terhadap informasi batu ginjal.

Setelah itu untuk mengetahui nilai window width yang optimal dalam memvisualisasikan informasi citra anatomi pada MSCT stonografi, peneliti menggunakan data informasi citra anatomi hasil penilaian responden yang dapat dilihat pada hasil uji Friedman pada tabel 2. yang menunjukkan bahwa window width $300 \mathrm{HU}$ dengan mean rank 
3.54, window width $350 \mathrm{HU}$ dengan mean rank 3.48, window width $400 \mathrm{HU}$ dengan mean rank 3.14 , window width $450 \mathrm{HU}$ dengan mean rank 2.74, dan window width $500 \mathrm{HU}$ dengan mean rank 2.30. Sehingga dapat disimpulkan bahwa window width $300 \mathrm{HU}$ memiliki nilai mean rank yang tertinggi yang artinya window width $300 \mathrm{HU}$ merupakan window width yang mampu memberikan informasi citra anatomi pada MSCT stonografi secara keseluruhan paling baik diantara variasi lain yang diuji.

\section{Pengaruh variasi window width terhadap informasi citra anatomi MSCT stonografi}

Hasil data penelitian diolah menggunakan uji stastika friedman dimana uji statisika friedman tersebut dapat digunakan sebagai dasar untuk menentukan pengaruh variasi window width terhadap informasi citra anatomi yang sudah ditentukan sebelumnya. Untuk mengetahui pengaruh tersebut adalah dengan dilakukannya uji friedman terhadap seluruh anatomi yang sudah ditentukan dan selanjutnya dijabarkan ke masingmasing anatomi. Kemudian diperoleh hasil Asymp. Sig lebih kecil dari 0,05 ( $<<0,05)$ yang artinya ada perbedaan dari perubahan variasi window width yang dapat juga diartikan bahwa perubahan variasi window width berpengaruh terhadap informasi citra anatomi yang dibaca oleh dokter radiolog sehingga dapat disimpulkan Ha diterima.

Pada MSCT stonografi, urolilthiasis atau batu ginjal tampak radiopaque atau berwarna putih terang sama seperti warna tulang. Ini disebabkan kerapatan dari batu ginjal yang sangat tinggi sehingga menghasilkan nilai HU yang tinggi juga. Sedangkan pada parenkim ginjal, pelvic calices ginjal, ureter, dan vesica urinaria tampak intermediet atau sama dengan organ pada abdomen lainnya. Keempat anatomi tersebut merupakan soft tissue sehingga menyebabkan nilai $\mathrm{HU}$ yang homogen pada keempat anatomi tersebut.
Menurut Lampignano (2018), perubahan nilai window width akan menunjukkan nilai perbedaan kualitas citra pada setiap rentang $50 \mathrm{HU}$. Window Setting Abdomen memiliki rentang baik pada 300 HU-500 HU. Pengaruh dari perubahan nilai window width yaitu berubahnya nilai kontras resolusi dan noise. Kontras resolusi dikatakan baik apabila mampu menunjukkan batas yang tegas antara objek yang saling berdekatan. Selain itu, noise juga perlu diperhatikan karena semakin tinggi noise yang dihasilkan, semakin kabur gambaran yang dihasilkan.

Menurut Ballinger (2016), efek dari perubahan nilai window width dengan nilai window level tetap adalah semakin tinggi nilai window width maka kontras gambar akan berkurang/menurun, semakin rendah nilai window width, maka kontras gambar menjadi bertambah/naik. Citra yang baik merupakan citra yang bisa menghasilkan kontras yang optimal sehingga sharpness atau ketajaman citra tersebut dapat terlihat.

Perubahan kontras yang diakibatkan oleh perubahan nilai window width akan memengaruhi terhadap kejelasan dari setiap anatomi, seperti apabila resolusi kontras anatomi ureter terlalu tinggi atau terlalu rendah maka akan mengaburkan gambaran struktural dari anatomi tersebut. Perubahan variasi window width pada $300 \mathrm{HU}$ dan $350 \mathrm{HU}$ cenderung menampakkan gambar yang lebih jelas dan sedikit noise. Anatomi yang dinilai mampu ditunjukkan dengan baik. Sedangkan pada variasi window width $400 \mathrm{HU}, 450 \mathrm{HU}$, dan 500 HU cenderung menunjukkan kontras resolusi yang menurun. Sharpness dari anatomi yang dinilai mulai samar samar sehingga kurang baik untuk dinilai oleh radiolog. Namun, perubahan nilai window width pada rentang window setting abdomen tidak berpengaruh pada batu ginjal. Rentang kontras resolusi pada window setting abdomen hanya merubah resolusi kontras pada jaringan soft tissue saja, dikarenakan kerapatan batu ginjal yang begitu tinggi yang mengakibatkan 
nilai HU batu ginjal akan tinggi juga sehingga tidak merubah kontras dari batu ginjal. Batu ginjal tetap terlihat jelas dan sharpness yang tegas.

\section{Nilai Window Width yang mampu menampilkan informasi citra anatomi lebih optimal pada MSCT stonografi}

Pada pemeriksaan MSCT stonografi penggunaan nilai window width pada window setting abdomen yaitu rentang nilai 300-500 HU (Bontrager,2018). Nilai Window Width yang sekarang menjadi acuan untuk MSCT stonografi 400 HU (Merrill, 2016). Menurut Seeram (2018) nilai window width pada window abdomen yang digunakan pada pemeriksaan MSCT stonografi adalah $350 \mathrm{HU}$. Menurut Chou dkk (2005) pemeriksaan MSCT stonografi menggunakan window width $300 \mathrm{HU}$. Menurut penelitian yang dilakukan Romain dkk (2010) peneliti menggunakan modalitas MSCT untuk menentukan karakteristik batu ginjal pada manusia dengan pemeriksaan MSCT abdomen menggunakan nilai window width $350 \mathrm{HU}$ pada window abdomen. Penggunaan window width pada pemeriksaan MSCT abdomen menurut Andersson dkk (2012) untuk mengevaluasi estimasi ukuran batu ginjal menggunakan nilai window width $400 \mathrm{HU}$. Sedangkan menurut jurnal penelitian yang dilakukan Yasir dkk (2015) untuk mengukur dimensi batu pada ginjal menggunakan nilai window width $400 \mathrm{HU}$.

Dalam penelitian ini peneliti menggunakan window width $300 \mathrm{HU}, 350 \mathrm{HU}, 400 \mathrm{HU}, 450 \mathrm{HU}$, $500 \mathrm{HU}$ yang bertujuan untuk melihat window width yang optimal dalam menampilkan informasi citra anatomi. Berdasarkan data penelitian yang dihasilkan, nilai window width yang optimal dapat dilihat melalui hasil mean rank tertinggi pada hasil uji friedman pada tabel 2. Pada tabel 2. Hasil uji friedman kelima variasi yang memiliki nilai mean rank tertinggi yaitu window width $300 \mathrm{HU}$ sebesar 3,54. Menurut peneliti window width $300 \mathrm{HU}$ memiliki kontras yang lebih tinggi sehingga menghasilkan batas-batas tegas antar anatomi yang berdekatan, selain itu juga mampu menampilkan gambaran yang jelas tanpa adanya blur pada citra. Window width $300 \mathrm{HU}$ mampu menampilkan informasi citra anatomi paling baik dikarenakan mampu memberikan kontras yang optimal sehingga mempermudah radiolog dalam mendapatkan informasi pada citra yang akan dinilai.

Berdasarkan hasil uji friedman per-anatomi pada tiap variasi menunjukkan pada tiap variasi menunjukkan anatomi parenkim ginjal, pelvic calices ginjal, ureter, vesica urinaria, dan tambahan yaitu batu ginjal menunjukkan nilai mean rank tertinggi yaitu pada window width $300 \mathrm{HU}$. Menurut peneliti dengan penggunaan window width yang optimal dapat memberikan nilai kontras resolusi yang optimal sehingga sharpness dari anatomi yang akan dinilai akan terlihat tegas dan akan bernilai informatif. Hasil citra tersebut mencitrakan anatomi pada MSCT stonografi yang tampak homogen dengan anatomi selain dari yang dinilai pada MSCT stonografi, tetapi anatomi yang dinilai tersebut mampu menunjukkan kontras resolusi yang baik dengan membedakan border line dari anatomi yang dinilai dengan anatomi terdekatnya, dan memiliki sharpness yang tegas sehingga dapat menampilkan kejelasan anatomi yang optimal pada citra pemeriksaan MSCT stonografi, yaitu dengan menggunakan window width $300 \mathrm{HU}$.

\section{Simpulan}

Berdasarkan hasil penelitian dan pembahasan bahwa perubahan nilai window width berpengaruh terhadap informasi citra anatomi MSCT stonografi. Kesimpulan tersebut diperoleh dari hasil uji friedman yang menunjukkan Asymp Sig 0,000 atau lebih kecil dari $0,05(\mathrm{p}<0,05)$ yang artinya terdapat perbedaan penggunaan variasi window width terhadap informasi citra anatomi. Dengan adanya nilai perbedaan tersebut perubahan nilai window width berpengaruh terhadap informasi 
citra anatomi MSCT stonografi. Semakin tinggi nilai window width yang digunakan maka kontras citra akan menurun, sebaliknya semakin tinggi nilai window width maka kontras citra akan bertambah/naik. Window width yang optimal adalah window width yang mampu menghasilkan gambaran citra dengan sharpness yang tegas dengan gambaran yang detail tanpa blur.

Hasil uji mean rank friedman menunjukkan nilai window width yang mampu menampilkan informasi citra anatomi lebih optimal pada citra MSCT stonografi yaitu window width 300 HU dengan nilai mean rank 3,54. Nilai tersebut mampu menghasilkan anatomi parenkim ginjal, pelvic calices ginjal, ureter, vesica urinaria, dan tambahan yaitu batu ginjal dengan sharpness yang tegas, citra yang dihasilkan lebih jelas dan tidak ada blur pada gambaran citra tersebut.

\section{Daftar Pustaka}

Bontrager, K.L., Lampignano, J.P. 2018. Bontrager's Textbook of Positioning and Related Anatomy. Seventh Edition. CV. Mosby Company, St. Louis.

Mehmed, M.M., \& Ender O., (2015). Effect of urinary stone disease and it's treatmen on renal function.World J Nephro: 4(2):271-276l.

Niemann, T., Straten V., Resinger C., Bayer T., Bongartz G. 2010, Detection of Urolithiasis Using Low-Dose Simulation Study. Uropean Journal of Radiology.

Sulaksono N, Suryono S, Ardiyanto J 2016. Optimalisasi Citra MSCT Traktus Urinarius Menggunakan Tracking dengan Variasi Slice Thickness dan Window Setting. JRK. May;5(1):30-4.

Sulaksono N, Suryono S, Ardiyanto J 2017. The optimization of ureterolithiasis image with a contrast analysis on MSCT of urinary tract with variation of slice thickness and window setting. Adv Sci Lett. Mar;23(3):2277-80.

Seeram, E. 2018. Computed Tomography : physical principles, clinical applications, and quality control. Third edition. WB Saunders Company, Philadelphia.

Yasir, a., Patino M., Kambadakone Avinash. 2015, Advances in CT imaging for urolithiasis. Uropean Journal of Radiology

Romain, G., Benoit S., Matias G., Daudon M. 2010, Charecterization of Human renal Stones with MDCT : Advantage of DualEnergy and Limitations Due to Respiratory Motion. Uropean Journal of Radiology. 